Київський національний університет культури імистецтв,

\title{
ХУДОЖНЬО-ЕСТЕТИЧНА ТА УТИЛІТАРНА СКЛАДОВІ ФЕШН ПРОЕКТУ
}

Стаття присвячена актуальній проблемі пошуку узагальненої методики художнього проектування сучасного одягу, здатної забезпечити органічну інтеграчію художньо-естетичних та утилітарних складових фешн-проекту.

Приведено структуру, зміст етапів та алгоритм узагальненої методики художнього проектування сучасного одягу. У ролі механізму інтеграції художньоестетичного та інженерно-аналітичного підходів до проектування обрано тандем морфологічного аналізу та творчого синтезу, використання якого у структурі узагальненої методики художнього проектування сприяє підвищенню ефективності пошуку інноваційних дизайнерських рішень.

Ключові слова: методика художнього проектування, інтеграція художньоестетичних та утилітарних складових, морфологічний аналіз-синтез.

Статья посвящена актуальной проблеме поиска обобщенной методики художественного проектирования современной одежды, способной обеспечить органичную интеграцию художественно-эстетических и утилитарных составляюших фешн-проекта.

Приведены структура, содержание этапов и алгоритм обобщенной методики художественного проектирования современной одежды. В роли механизма интеграции художественно-эстетического и инженерно-аналитического подходов $\kappa$ проектированию избран тандем морфологического анализа - творческого синтеза, использование которого в структуре обобщенной методики художественного проектирования оказывает содействие повышению эффективности поиска инновационных дизайнерских решений.

Ключевые слова: методика художественного проектирования, интеграция художественно-эстетических и утилитарных составляющих, морфологический анализ-синтез.

The article is devoted the problem of finding a generalized method of modern clothes fashion design, which able to provide seamless integration of art-aesthetic and utilitarian components in common process of projecting.

The structure, content and stages of the algorithm of the generalized method of modern clothes design were characterized.

In the role of the mechanism of integration of art-aesthetic and engineer-analytical approaches to the design the tandem of morphological analysis - creative synthesis was chosen. 
It is shown, that the use of this tandem in the structure of the common methodology of fashion design promotes of increasing the finding process efficiency of innovative design solutions.

Key words: methodology of fashion design, integration of art-aesthetic and utilitarian components, morphological analysis - synthesis.

Дизайн як специфічна сфера діяльності, що покликана надати речам одночасно функціонального, естетичного та морального змісту, є біфункціональним. Двоїста природа дизайну проявляється у тому, що він пов'язаний і з художньою, і з технічною підсистемами культури [1, с. 16].

Художньо-естетичні та утилітарні компоненти дизайнерської творчості ставлять перед дизайнером суперечливі вимоги. Наприклад, досконалий із погляду естетичних властивостей об'єкт може бути функціонально неефективним або економічно недоцільним. Розуміння дизайну як предметно-перетворюючої діяльності, що сприяє відновленню цілісності матеріальної й духовної культури в умовах науково-технічного і соціального прогресу, сприяє подоланню своєрідного антагонізму інженернотехнічного і художнього поглядів на його природу, а також усуненню протиріч спеціалізованих методик, що розроблені під впливом типологічних розходжень об'єктів проектування у різних галузях виробництва $[15$, с. 6$]$.

Біфункціональність дизайну припускає різноманітні варіанти інтерпретації, які частково перекриваються, що дозволяє краще зрозуміти різні аспекти, які породжують багатофункціональність.

У роботах $[1 ; 2 ; 14 ; 15]$, присвячених побудові концепцій дизайну, він представлений як сфера матеріальної культури і мистецтва, що включає у себе утилітарні і естетичні цінності, а об'єкти дизайну розглядаються як частина соціального середовища і як частина матеріально-просторового оточення людини. Відзначається, що ці дві сторони кожного твору дизайну невід'ємні та не можуть існувати один без одного [15].

У статті [4], що присвячена аналізу факторів підвищення ефективності художнього проектування, дизайн інтерпретується як суперпозиція двох типів процесів різної природи - процесів, що засновані на художньо-естетичному творенні, і процесів організаційно-технологічного характеру, що допускають алгоритмізацію. У статті [3] модель дизайну заснована вже на трьох компонентах - художньо-естетичному, утилітарному та соціальному.

Незважаючи на всебічний аналіз проблем і критику особливостей розвитку дизайну в умовах масової культури, у публікаціях останніх років не зазначено шляхи відновлення аксіологічних орієнтирів дизайну, не дано рекомендації щодо реставрації діалогу між дизайнером і споживачем. У результатах досліджень, присвячених аналізу та пророкуванню шляхів розвитку дизайну, не розглянуто підходи, що спрямовані на гармонійне сполучення художньо-естетичної та утилітарної складових дизайнпроектування.

Оскільки дизайнерська творчість може бути ефективною лише за умов гармонії між внутрішніми процесами різної природи, з яких складається дизайн, стає актуальною проблема гармонійної інтеграції художньо-естетичної та утилітарної складових дизайнпроекту у межах загальної концепції. 
Результати досліджень костюма і тенденцій розвитку методики його художнього проектування можна умовно поділити на три групи.

Перша група утворена варіантами культурологічних і мистецтвознавчих підходів до побудови концепції фешн-дизайну та методики проектування сучасного одягу. У статті О. С. Самоненко [17] концепція дизайнерської творчості заснована на асоціативно-образному аспекті. Культурологічний аналіз піднімає ряд проблем, що існують нині в дизайні костюма, у контексті підходів до процесу проектування головною 3 яких визначено проблему відсутності системного підходу. У статті розглянуто основні принципи сучасного проектування костюма на основі асоціативно-образного методу, що дозволяють оптимізувати процес творчих пошуків, підвищити його результативність і максимально розкрити творчий потенціал дизайнера. Концепція фешн-дизайну за матеріалами статті О. В. Секачевої [18] будується на виявленні образно-інформаційної структури сучасної моди. В. Ф. Сидоренко використає мистецтвознавчий підхід до дослідження взаємодії між генезисом проектної культури та естетикою дизайнерської творчості [19]. Також з позицій мистецтвознавчого підходу до аналізу естетичних аспектів проектування костюма звертається А. Л. Мильман, який у своєї праці інтерпретує феномен моди як форми театралізації життя [12]. Характерними представниками першої групи є матеріали книги Т. В. Козлової, Л. Б. Ритвинскої, 3. Н. Тімашової, що присвячена моделюванню та художньому оформленню жіночого та дитячого одягу [7], книга 3. Тканко, О. Коровицького (Моделювання костюма в Україні ХХ століття) [20], матеріали М. А. Коробцевої [9], І. А. Кузнецової, Е. В. Бессарабової, С. Л. Тарнавскої [11], що присвячені імпресивному підходу щодо проектування костюма.

Оскільки ця група робіт характеризується мистецтвознавчим поглядом на природу фешн-дизайну, акцент у ній доводиться на аксіологічні аспекти художньо-естетичного характеру, тоді як утилітарним і функціонально-конструктивним аспектам приділяється менше уваги. Це надає концепції деякої однобічності, у результаті чого проблеми фешндизайну проектуються на площину естетичних критеріїв.

Друга група представлена варіаціями функціонально-конструктивного і художньотехнологічного підходів до вирішення проблем дизайну одягу. Характерні результати цієї групи представлені роботами Г. І. Петушкової (Трансформативное формообразование в дизайне костюма) [13], Н. В. Чупріної (Розробка художньотехнологічних принципів проектування колекції сучасного жіночого костюма на основі українського народного одягу) [21], О. И. Косенко (Анализ научных подходов к эволюции формы костюма) [10]. Ці матеріали також характеризується деякою односпрямованістю, у результаті чого проблеми фешн-дизайну проектуються на площину функціонально-конструктивних або морфологічних критеріїв, а художньоестетичні аспекти творчості презентовані як критерії другого рівня.

Третя група характеризується дослідженнями з використанням комплексного підходу до аналізу проблем фешн-дизайну. До цієї групи відносяться матеріали книги Т. В. Козлової, Е. В. Іллічової, що присвячена аналізу стилю у костюмі ХХ століття [8]. Матеріали книги викладено в нестандартній формі, що дозволяє порівняти культурологічний і математичний підходи до дослідження тенденцій розвитку стилю у костюмі різних епох. До третьої групи відносяться наукові праці В. В. Давидової(Досвід 
системного розгляду костюма) [6], I. А. Гардабхадзе (Дизайн-проектування. Сучасний одяг: науковий підхід до вирішення проблем дизайну) [5], (Оцінка результатів дизайнпроектів на основі моделі збалансованого трикутника ефективності) [3], О. С. Самоненко (Асоціативно-образний метод проектування костюма). Висновки досліджень О. С. Самоненко у тому числі містять наступні твердження: нерозуміння складності структури та основних функцій концептуально-образного рішення сучасного костюма змушує дизайнера користуватися єдиним доступним творчим інструментом - інтуїцією. Однак для створення костюма як продукту проектної діяльності «інтуїтивного підходу, що стимулюється творчим натхненням, недостатньо. Існує необхідність розробки й використання комплексного інтуїтивного-аналітичного підходу» [16].

Аналіз основних результатів досліджень проблем фешн-дизайну показав, що у жодній з трьох груп напрямів досліджень не реалізовано гармонічну інтеграцію культурологічного, мистецтвознавчого, функціонально-конструктивного та проектноаналітичного підходів. У той же час проектний характер дизайнерської творчості вимагає формування проектно-художнього мислення, заснованого на феномені проектної культури. На наступному рівні розвитку теорії художнього проектування «технології» творчого процесу, які необхідні для створення моделей сучасного костюма, недостатньо розроблені. Залишаються невирішеними ряд питань, а саме:

- Як взаємодіють художньо-естетичні, функціонально-цілеспрямовані та утилітарні складові у межах єдиного процесу художнього проектування моделей колекції сучасного одягу?

- Як оцінити ефективність гармонійної інтеграції художньо-естетичної та утилітарної складових дизайн-проекту у модифікованій методиці проектування сучасного одягу?

Темою цієї роботи обрано дослідження особливостей естето-утилітарної концепції фешн-дизайну.

Метою статті є побудова у межах естето-утилітарної концепції фешн-дизайну методики художнього проектування, яка гармонійно об'єднає у єдиному процесі художньо-естетичні, функціонально-конструктивні та утилітарні підходи до створення колекцій сучасного одягу.

Під естето-утилітарною концепцією фешн-дизайну будемо розуміти модель, що представляє дизайн-процес суперпозицією двох процесів різної природи: процесу, для якого пріоритетними є художньо-естетичні критерії, i процесу, для якого пріоритетом є оптимізація утилітарних показників. Така концепція призводить до вимог гармонійної взаємодії культурологічного та конструктивно-функціонального підходів щодо проектування. Проблема побудови концепції фешн-дизайну, заснованої на гармонійній взаємодії культурологічного та конструктивно-функціонального підходів, полягає у знаходженні ефективного механізму балансування характеристик процесів різної природи, які характеризуються художньо-естетичними й утилітарними параметрами. Механізм балансування повинен бути вбудований в узагальнену методику художнього проектування.

Історія дизайну свідчить про те, що культура масового споживання призвела до втрати звичних аксіологічних орієнтирів у дизайні, що перетворило споживання в процес 
задоволення символічних, а не реальних потреб. У статті [1] йдеться про те, що в постмодерністському дискурсі «художник не открыт для диалога. ... Однако развитие культуры должно привести к возобновлению диалогических отношений дизайнера и потребителя в области художественного проектирования». Як протест проти шаблонності масової культури в суспільстві зароджуються тенденції індивідуалізації та екологізації, спрямовані на реставрацію класичних аксіологічних критеріїв дизайну, на конвергенцію естетичної й утилітарної складових.

У фешн-дизайні нового покоління тенденції проявляються у переході від мистецтвознавчого до проектного підходу розробки моделей сучасного одягу, що вимагає формування проектно-художнього мислення, заснованого на феномені проектної культури. У методології дизайну поняття «проектна культура» стало концептуальним орієнтиром, що визначає розгляд дизайну у культурологічному вимірі [14, с. 189]. У теорії і практиці художнього проектування сучасного одягу проектна культура є основою професійної компетентності фешн-дизайнерів.

Проектна культура фешн-дизайну, що спрямована на реставрацію діалогу «дизайнер-споживач», з'явилася базою для побудови узагальненої методики художнього проектування, яка сприятиме гармонійної інтеграції художньо-естетичних та утилітарних складових в одному процесі. Узагальнена методика характеризується складом послідовних стадій проектування:

- передпроектне дослідження вимог ринку індустрії моди;

- генерація авторської проектної ідеї;

- пошук, аналіз, класифікація та типізація елементів творчих першоджерел $\mathrm{s}$ тенденцій моди;

- комбінування перспективних комбінаціq елементів першоджерела та сучасного одягу;

- творчий синтез характерних елементів першоджерел та елементів-носіїв тенденцій моди;

- візуалізація дизайнерських рішень у двомірних ескізах;

- матеріалізація у тривимірних моделях.

Структура алгоритму узагальненої методики проектування може бути представлена на основі системного підходу трьома основними етапами та експериментальним етапом з декількома підзадачами у кожному [4].

На першому етапі системного підходу формується планування проекту, визначається методологія дослідження характерних рис першоджерел, уточнюється алгоритм побудовю дизайнерського рішення і формулюється підхід до експериментальної оцінки результатів проектування. Цей етап має загальнометодологічний характер.

Другий етап - етап аналізу і класифікації, в ході якого досліджуються матеріали та виконується класифікація творчого джерела й тенденцій світової моди. Далі будуються узагальнені типізовані елементи першоджерела та узагальнені типізовані елементи одягу за світовими тенденціями моди провідних країн світу. Знайдені узагальнені (типізовані) елементи творчого першоджерела та сучасного костюма виконують роль вихідних елементів для творчого синтезу.

На третьому етапі відбувається творчий синтез узагальнених елементів першоджерел та елементів-носіїв характерних рис світових тенденцій моди. Отримані 
синтезовані елементи мають риси творчого першоджерела та відповідають напрямам моди, що дозволяє успішно використати їх у нових дизайнерських рішеннях сучасної колекції.

Завершальним етапомє експериментальний етап. У нього входять експериментальна перевірка на моделях під час демонстрації моделей і суб’єктивна оцінка ефективності знайдених рішень.

Оскільки логічна модель дизайну заснована на абстрактних поняттях «морфологія» та «аксіологія» речі, треба знайти цілісний ефективний механізм генерації дизайнерських рішень, що відображає морфологію та аксіологію дизайнерських творів. У ролі такого механізму, що також здатний ефективно забезпечити інтеграцію художньо-естетичної та утилітарної складових фешн-проекту, обрано тандем морфологічного аналізу та творчого синтезу.

У морфологічному аналізі використовуються два типи об’єктів-вихідні прототипи, які повинні бути поліпшені, та творчі першоджерела. Для підвищення якісних характеристик об'єкта, що проектується, здійснюється комбінування типізованих елементів, які представляють вихідний прототип, з типізованими елементами, за допомогою яких представлено творче першоджерело. Із комбінацій елементів відбираються ті, що мають найкращі якості. Таким шляхом можна гармонійно об' єднати найкращі художньо-естетичні та утилітарні параметри прототипу та творчого першоджерела У результаті з безлічі пар вихідних елементів будуть обрані комбінації 3 найкращими характеристиками, які у процесі творчого синтезу утворять нові об'єкти з художньо-естетичними й утилітарними характеристиками, збалансованими відповідно до заданих критеріїв. У результаті оптимального балансування характеристик різної природи деякі показники синтезованого об'єкта (відповідно заданим пріоритетам) будуть кращі відповідних показників прототипу, а інтегральна оцінка дизайнерського рішення буде вищою інтегральної оцінки вихідного об'єкта.

Цінною властивістю морфологічного аналізу є поєднання аналітичних і евристичних механізмів його проведення. У результаті їх гнучкого об'єднання в одному процесі 3'являється можливість формального урахування всієї безлічі комбінацій вхідних елементів (аналітична складова), а також інтуїтивного відбору і творчого поєднання перспективних комбінацій елементів із параметрами, які володіють найбільш високим потенціалом ефективного створення інноваційного дизайнерського рішення (евристична складова) [5, с. 152, 153].

Таким чином, у межах естето-утилітарної концепції фешн-дизайну запропоновано методику художнього проектування, у яку вбудований ефективний механізм інтеграції художньо-естетичного та функціонально-конструктивного підходів щодо проектування. Проблему органічної інтеграції художньо-естетичної та утилітарної складових фешнпроекту вирішено на основі модифікації узагальненої методики художнього проектування, заснованої на тандемі морфологічного аналізу - творчого синтезу типізованих елементів першоджерела та елементів-носіїв тенденцій моди.

Перспективи подальших досліджень полягають у визначенні та деталізації індикаторів, що характеризують групи художньо-естетичних та утилітарних складових 
фешн-проекту, з наступним використанням поширеної системи індикативних параметрів для удосконалення методики морфологічного аналізу - творчого синтезу дизайнерських рішень сучасного одягу.

\section{Jimepamypa:}

1. Бараш Л. А. Аксиологические аспекты дизайна в сфере межсубъектных отнотений / Бараш Л. А. // Исторические, философские, политические и юридические науки, культурология и искусствоведение. Вопросы теории и практики. - Тамбов : Грамота, 2011. - № 4 (10) : в 3-х ч. - Ч. ІІ. - С. 16-18. 2. Безмоздин Л. И. В мире дизайна / Безмоздин Л. И. - Ташкент : Фан, 1990. - 325 с. 3. Гардабхадзе І. А. Оиінка результатів дизайн-проектів на основі моделі збалансованого трикутника ефективності / Гардабхадзе I. А. // Питання культурологї : зб. наук. праџь. - вип. 30. - Київ : КНУКіМ, 2014 р. - С. 184-191. 4. Гардабхадзе I. А. Аналіз факторів підвищення ефективності прочесів створення сучасного одягу / Гардабхадзе I. А. // «Вісник» КНУТД. - 2009. - № 6. C. 119-123. 5. Гардабхадзе I. А. Дизайн-проектування. Сучасний одяг: науковий підхід до вирішення проблем дизайну [Рекомендовано МОН Украӥни як навчальний посібник з курсу «Дизайн-проектування»] / Гардабхадзе I. А. - Київ : «Издательский дом Виниченко», 2013. 275 с. 6. Давидова В. В. Опьт системного рассмотрения костюма / Давыдова В. В. // Материальл международной научной конференции. 18 мая 2001 г. Санкт-Петербург. Серия «Sутровіum». - Bыл. № 12. - Санкт-Петербург : Санкт-Петербургское философское общество, 2001. - С. 287-290. 7. Козлова Т. В. Моделирование и художественное оформление женской и детской одежды / Т. В. Козлова, Л. Б. Рытвинская, 3. Н. Тимамева. [2-е изд., перераб. и доп.]. - Москва : Лёгпромбытиздат, 1990. - 318 с. 8. Козлова Т. В. Стиль в костюме ХХ века : учеб. пособ. для ВУЗов / Т. В. Козлова, Е. В. Ильичева. - Москва : МГТУ им. А. Н. Косыгина, 2003. - 160 с. 9. Коробцева М. А. Проектирование одежды. Импрессивньй подход/Коробиева М. А.-Москва: «Гноми Д», 2001.-160 с. 10. КосенкоО. И. Анализ научных подходов к эволючии формы костюма [Электронный ресурс] / О. И. Косенко. Режим доступа: http://www.icp-ua.com/ru/node/1249. - Дата доступа 10.02.2012. - Загл. с экрана. 11. Кузнецова И. А. Импрессивный подход на примере дизайна одежды [Электронный ресурс] / И. А. Кузнецова, Е. В. Бессарабова, С. Л. Тарнавская // Наукові нотатки. -2008. - Bun. 22. - T. 2. - C. 176-184. - Режим достуna: http://www.nbuv.gov.ua/ portal/natural/Nn/2002_2009/naunot15.htm. - Дата достуnа: 25.03.2012. - Назва з екрана. 12. Мильман А. Л. Мода как форма театрализации жизни: (эстетические аспекть проектирования костюма) : дис. ... канд. искусствоведения: 17.00.16 / А. Л. Мильман. Москва, 1998. - 184 с. 13. Петушкова Г. И. Трансформативное формообразование в дизайне костюма / Г. И. Петушкова. - Москва : МГУДТ, 2010. - 201 с. 14. Пойдина Т. В. Аксиологические аспекты проектной культуры и формирование проектно-компетентной культуры студентов в системе профессионального обучения (дизайн) / Пойдина Т. В. // Известия АлтГУ. - № 2 (82). - Т. 2. - Барнаул : АлтГУ, 2014. - С. 189-193. 15. Сайт института технической эстетики. Грашин А. А. Утилитарные и эстетические начала в проектном дизайне / А. А. Грашин, В. ф. Рунге [Электронный ресурс]. - режим доступа: www.advtech.ru/vniite/stat21.doc. - дата доступа -15.12.2015. - заглавие с экрана. 16. Самоненко О. С. Ассочиативно-образныйметод проектирования костюма: автореферат 
дис. ... канд. искусствоведения : 17.00.06- техническая эстетика и дизайн / О. С. Самоненко. Санкт-Петербург, 2011. - 24 с. 17. Самоненко О. С. Творчество дизайнера костюма: ассоциативно-образный аспект // Вестник Челябинского государственного университета. № 17. - Филология. Искусствоведение. Вып. 44 - Челябинск : Изд. ЧГУ, 2010. - С. 180-184. 18. Секачева О. В. Выявление образно-информационной структуры современной российской моды : дис. ... канд. техн. наук: 05.19.07/О. В. Секачева.-Москва, 1999. - 196 с. 19. Сидоренко В. Ф. Генезис проектной культуры и эстетика дизайнерского творчества : автореф. дис. на соиск. ученой степ. д-ра искусствоведения : 17.00.06 / В. Ф. Сидоренко .-Москва, 1990. 32 с. 20. Тканко 3. Моделювання костюма в Украӥні ХХ століття : навч. посіб. для студ. навч. закл. мистецтва і легкої пром-сті, художників, мистецтвознавців / 3. Тканко, О. Коровицький. - Л. : Вид-во «Брати Сиротинські і К», 2000. - 96 с. 21. Чупріна Н. В. Розробка художньо-технологічних принщипів проектування колекиії сучасного жіночого костюма на основі українського народного одягу : автореф. дис. на соиск. ученой степ. канд. техн. наук : 05.19.04 / Н. В. Чупріна. - Київ : КНУТД, 2001. - 15 с. 